\title{
1960'larda Sürdürülebilirlik ve Kentleşme; Isparta İstasyon Caddesi Örneği
}

\author{
Hasan HAŞTEMOĞLU ${ }^{1 *}$, Levin ÖZGEN² \\ ${ }^{1}$ Süleyman Demirel Üniversitesi, Mimarlık Fakültesi, Mimarlık Bölümü, 32260, Isparta, Türkiye. \\ ${ }^{2}$ Abant İzet Baysal Üniversitesi, iktisadi ve Idari Bilimler Fakültesi, Kamu Yönetimi Bölümü, \\ 14280, Bolu, Türkiye. \\ * e-mail:hasanhastemoglu@sdu.edu.tr \\ Öz \\ Sürdürülebilir kentleşmenin gerçekleştirilebilmesinde kentlerdeki mülkiyet biçiminin ve etkilerinin rolü büyüktür. \\ Isparta kenti, istasyon Caddesi ve çevresindeki 1960 sonrası kentleşmede yaşanan dönüşümler bu açıdan önemli \\ dersler çıkarılabilecek bir örnektir. 1960 sonrasında yaşanan dönüşümler sonucunda, alanın mülkiyet yapısının \\ Kat Mülkiyeti Kanununun getirdiği olanaklar doğrultusunda parçalı bir yapıya dönüşmesi ve özel mülkiyetin \\ egemen olması, alana sürdürülebilir kentleşme olanaklarını baştan engelledi denebilir.
}

Anahtar Kelimeler: Sürdürülebilirlik, sürdürülebilir kentleşme, kentsel toprak, mülkiyet, kat irtifakı

\section{Sustainability and Urbanization in the Years of 1960s; Isparta, İstasyon Boulevard Sample}

\begin{abstract}
The mode of property and its effects are of utmost importance in realization of sustainable urbanization. Also transformations experienced in urbanization after 1960s in Istasyon Boulevard and nearby within the city of Isparta are important examples from which essential lessons could be derived. As a result of these transformations experienced after 1960s, it could be said that transformation of structure of land property into a multi-parted ones within the possibilities that brought by Condominium Codes prevented any opportunity for development of sustainable urbanization from early beginning.
\end{abstract}

Keywords: Sustainability, sustainable urbanization, property relations, condominium, real servitude

\section{Giriş}

Sürdürülebilirlik konusu 2000'li yıllarda insanlığın temel gündem maddelerinden biridir. Bu haliyle kentlerde önemli bir paradigmatik dönüşüm yaratmıştır. Sürdürülebilirliğin temel bileşenleri çevre boyutu, sosyal boyutu ve ekonomik boyutudur. Sürdürülebilirliğin inşa edilebilmesi bu ana başlıklar altında yer alan değerlerin ve koşulların gerçekleşebilmesine bağlıdır. Bu haliyle dahi geniş ve bir tezin kapasitesini aşan derin bir sorunsaldır. İ̧̧eriği bağlamında Gelişmiş - Gelişmemiş bütün ülkelerin üzerinde tartıştığı, her bireye yaşamsal standartların sağlanması sorunları, temelde, 18. yüzyılda Avrupa'da sanayi devrimiyle başlayan sürecin yansımalarıdır. Bunlar 19. yüzyıl sonlarına doğru tüm dünyada insanlığın dikkatini çeken büyük çevre sorunlarının ortaya çıkmasıyla kitlesel boyutlara ulaştı. Bu dönemden itibaren insanlığın gündemine çevrecilik ve doğa korumacılık fikirleri yerleşmeye başladı. İnsanlığın gündemine giren bu konular üzerinde pek çok fikir ve yaklaşım ortaya çıkarken, çevreye ve doğaya duyarlılık olgusunun bağlam ve içerik olarak gerçek kapasitesini 1980'lerde ortaya çıkan sürdürülebilirlik yaklaşımında bulduğu söylenebilir. Sürdürülebilirlik olgusunu pek çok tanımlama çabası olmasına rağmen, geniş kabul göreni "bugünün gereksinimlerini, gelecek kuşakların da kendi gereksinimlerini karşılayabilme olanağından ödün vermeksizin karşılamaktır" şeklindedir. 
Sürdürülebilirlik 1960 'larda ve 2000 'li yıllarda farklı içeriğe sahip, ancak temel hedefleri ile insanlığın ve mimari tasarımın bünyesinde hep var olan bir olgudur. İçerik gelişmesinin başlangıç dönemi, mimari tasarım ve kentleşme ile özel bir bağ içindedir. Çalışmada sürdürülebilirlik ve kentsel mülkiyet ilişkisi arasındaki etkileşimin yapılaşma ve yapı üzerindeki getirilerinin belirlenmesi hedeflenmiştir. Öyle ki, sürdürülebilir kentsel gelişme konusunda, Türkiye gibi ülkelerde görüldüğü üzere tarihi kültürel miras içinden süregelen pek çok olanağın, bu ülkelerde kentleşmenin hızlandığı 1950'lerden itibaren kaybedilmiştir. Oysa sürdürülebilirlik tüm insanlığın ortak sorunudur. Sorunun önemi büyükken, son birkaç yüzyılda meydana gelen büyük gelişmelere rağmen insanlığın çoğunluğu, henüz tam anlamıyla sağlıklı ve insanca bir yaşam için gerekli temel ihtiyaçlarını bile karşılayabilmiş değildir. Her ne kadar 1950'ler sonrasında ülkeler Gelişmişler, Gelişmekte Olanlar, Az Gelişmişler olarak sınıflandırılsa da, Gelişmiş denilen toplumların gelişmiş dedikleri metropoliten kentlerinde dahi sadece biraz daha dikkatli bakmakla fark edilebilecek pek çok gelişmemişlik öğesine rastlanır. En temel insan ihtiyaçları, temiz hava, temiz su ve barınma olanakları bile her bireye ulaşamamış durumdadır.

\section{Sürdürülebilir Kentleşme ve Kentsel Toprak Mülkiyeti}

Sürdürülebilirlik kavramı ilk kez 1977 yılında D. Pirages'in "Sürdürülebilir Toplum" adlı kitabında gündeme gelir (Tekeli, 1999). Ancak kavramın tüm dünya tarafından kabul görür konuma gelmesi, 1970'lerden sonra uluslararası boyutta üzerinde her türlü düzeyde tartışmanın yapıldığı çevre sorunlarına çözüm bulmak amacıyla, 1987'de Dünya Çevre ve Kalkınma Komisyonu'nun yayınladığı raporla gerçekleşir. "Ortak Geleceğimiz" adıyla bilinen raporda yer alan "Sürdürülebilir Kalkınma" ifadesi kavrama uluslararası çerçeve kazandırır (Ekinci, 1995). Sürdürülebilirlik 1960'larda ve 2000'li yıllarda farklı içeriğe sahip, ancak temel hedefleri ile insanlığın ve mimari tasarımın bünyesinde hep var olan bir olgudur. 1960 'lı yıllarda ekoloji ve çevre sorunsalının, 2000'lerde ise ekonomik, sosyal, kültürel kalkınmanın konusudur. Sürdürülebilirlik yaklaşımı, insanın ekonomik, sosyal, politik ve kültürel yaşamına ilişkin her olguyu kapsamına alır, ilişki kurar. Bu bağlamda tüm yaşamsal faaliyetlerin gerçekleştiği, aynı zamanda kirliliğin ve sürdürülebilirliği engelleyen faktörlerin en çoğunu üreten fiziki mekânlar olan kentlerin, sürdürülebilirlik yaklaşımıyla ilişkili olarak ele alınması kaçınılmazdır. Diğer deyişle kentler sürdürülebilirlik olgusunun üç temel bileşeniyle "ekonomik, sosyal ve ekolojik" doğrudan bağlantı kuran düğüm noktaları konumundadır (ACE, 2005).

Çünkü dünyada kentsel nüfusun hızla artışı ve kentleşme oranının \% 90'lara ulaşması, kentleri 21. yüzyılda insanlığın doğal yaşama alanı konumuna getirmiştir. Bu bağlamda sürdürülebilirlik tüm insanlık için slogan haline gelen ve kökeninde temel insan gereksinimlerinden biri olan barınma ihtiyacının karşılanması savından hareketle, "herkes için konut" yaklaşımından "herkes için yaşanabilir çevre" yaklaşımına kadar genişletilen bir içeriğe sahiptir. Sürdürülebilir yapılaşmanın ve kentleşmenin temel dayanağı ise planlı kentleşmedir. Planlı kentleşmenin sağlanabilmesi için, planlamanın yapılacağı kentsel toprak parçasının kamu yararı gözetilerek düzenlenebilmesi gerekir. Çünkü kentsel toprakların, kentsel arsaya dönüşmesinin sosyal maliyeti, planlı yerleşme kararları ve altyapı yatırımları ile oluşur. Yalnız kamunun katkıları ile değeri artan kent toprağı giderek metaya dönüşür (Yavuz, 1980). Kentte toplu yaşama, bu malın kullanılmasında kar dürtüsü, dolayısıyla da çıkar çatışmaları yaratır. Çatışma bir yandan kamu ile birey, diğer yandan doğrudan bireyler arasında oluşur (Keleş, 1984). Bireyci, toplum yararını göz ardı eden bu durumun, sürdürülebilir kentleşme ve kent yaklaşımıyla özünden çeliştiği görülür. Ayrıca sürdürülebilir kentleşme yaklaşımı açısından toprak gibi kıt ve yenilenemeyen bir kaynağın bilinçli ve düzenli kullanımı zorunluluktur. Böyle bir kaynağın toplum yararı düşünülmeksizin, özel inisiyatife bırakılması söz konusu olamaz. Diğer bir deyişle üretilemeyen bir meta olan topraktan yararlanmayı bireylerin kendi çıkarlarına göre düzenlemeleri uygun değildir (Okutan, 1995). Bununla birlikte, sürdürülebilir kentsel gelişmenin sebep sonuç ilişkileri, toprak ve toprağın özel kullanımı bağlamında düşünülmek durumundadır. Bunun için maliklere, sürdürülebilir kentsel gelişim için, toplum huzurunun, kişisel kazanç elde etmekten daha önemli olduğunu göstermek gerekir (Bullard, 2002). Diğer bir deyişle, birey yararı yaklaşımının ya da 
bireyci tasarım mantığının yerini kamu yararı ve toplumcu tasarım ideolojisine terk etmesi gereğidir (Incedayı, 2004).

Toprak mülkiyetinin çoğunlukla özel şahıslar elinde olduğu durumlarda kamu yararının gözetilebilmesi oldukça güçtür. Kişisel rant kaygılarına yenik düşme olasılığı yüksektir. Bu nedenlerle kamu yararı açısından kentsel topraklarda mülkiyet yapısına, devlet tarafından sınırlama getirilebilmesi gerekir. Bazı uygulamalarda tespit edilen değer üzerinden kamulaştırma yapılırken, bazı uygulamalarda kamu, bireylerle toprak takası yoluna giderek ihtiyaç duyduğu arsaları kamulaştırmaya çalışılmakta, bu yolla kentsel topraklarda kamu mülkiyeti miktarı arttırılmaya çalışılmaktadır (Jökel, 2003). Bu olgunun dünyanın pek çok ülkesinde uygulamaları bulunur. Örneğin İngiltere'de kentsel toprakların doğru kullanılması için, arsaların yapı ruhsatı alınmadan önceki ve sonraki değeri olmak üzere iki değer belirlenir. Mal sahibinin sadece birinci değerde hakkı vardır. íkinci değer ruhsat veren kamu kuruluşu tarafından yaratıldığı için ortaya çıkan değer farkı topluma aittir. Hollanda'da belediyeler genellikle kent toprakları üzerinde uzun süreli kira yöntemini uygulamaktadır. İsviçre'de ise belediyeler toprak stoku yapma politikasına yönelerek, belediye sınırları dışındaki toprakları zamanla belediye sınırları içine almaktadır (Yavuz, 1980).

Türkiye'de 1961 ve 1982 Anayasalarında yer alan, “Herkes, mülkiyet ve miras hakkına sahiptir. Bu haklar, ancak kamu yararı amacıyla, kanunla sınırlanabilir. Mülkiyet hakkının kullanılması toplum yararına aykırı olamaz" hükümleri ile mülkiyet hakkının kullanımına yasal sınırlamalar getirilmiştir. Ancak 1960'larda başlayan hızı kentleşme olgusunun, kentlerde arsa ihtiyacını artırarak, kentsel arsaların spekülasyon aracı olarak kullanılmasına neden olması, ucuz arsa ihtiyacının karşılanması için 1965 yılında Kat Mülkiyeti Kanununun uygulamaya koyulmasına neden olmuştur. Kanun ile bir yapının bağımsız bölümlerinin ayrı ayrı özel mülkler olarak kullanılması sağlanmıştır. Bu yolla, kısa vadede konut yapımı için gerekli arsa sorunu çözülmüş görülse de, Kat mülkiyeti kavramının içerdiği, özel mülkiyet ve parçalı mülkiyet olgularının sürdürülebilir kentleşme üzerinde olumsuz etkilere yol açtığı görülür. Bu etkiler temelde 4 başlıkta toplanabilir.

\subsection{Engel / Aşırı Yoğunluk Sorunları}

Özel mülkiyet sahiplerinin kendilerine en fazla yarar sağlayacağını düşündükleri kullanıma yönelmeleri, azami kar düşüncesi ile her türlü imar sınırının son seviyesinde kullanılması, sürdürülebilir kentleşmenin, toplum için yaşanabilir sağlıklı çevre oluşturma ilkesi ile çelişki yaratır. İmar kanuna aykırı olsa da bodrum katlar kullanıma açılır, çatı katları yükseltilir, açık çıkmalar kapatılır, ticari bölümler bahçe sınırlarına taşar. Toplumun geneli tarafından yapılan uygulamalar denetlenemez hal alır. Bu durum sürdürülebilir kentleşmenin özelliklerinden, insani boyut, estetik kaygı, parsel-yapı-yol uyumu, yapılaşma-yeşil alan dengesi gibi olgularıyla çatışır. Sonuç olarak yaşanabilir çevre özelliklerinden yoksun aşırı yoğunluklu yapılaşmaların ortaya çıkmasına neden olur.

\subsection{Engel / Karar Alma Süreci Sorunları}

Yeniden düzenleme gereken durumlarda mülk sahiplerinin bireysel çıkarlarını karşılamak zor olacağı için karar almak zorlaşır. Süreç gecikir ya da hiç gerçekleşmez. Kentsel alanda mevcut yapılaşmış alanların ıslahı, yenilenmesi veya kentin geleceği için ihtiyaç duyulan yeni fonksiyonların hizmete sokulması zorlaşır, kentsel çöküntü alanları oluşabilir. Bu tür alanların ıslahı kısa vadede mümkün olmadığından, bireyler kısa zamanda kendilerini bu bölgelerden uzaklaştırmaya çalışır. Kentlerin merkezinde yer alan önemli bölgeler kaybedilirken, bölgelerini terk edenler, kent dışındaki uydu kentlere yönelir. Kent ve çevresinde ulaşım yoğunluğu, dolayısı ile çevre kirliliği ve enerji kullanımı artar.

\subsection{Engel / Kentsel Donatı Alanı Sorunları}

Özel mülkiyetin ve mülkiyet parçalanmasının kentsel topraklar üzerinde egemen olması nedeniyle, yeterli kamusal toprak bulunmaması sonucunda, kentsel donatı ihtiyaçları, küçük, parçalı ve kıt olan kamu mülkü topraklarda, konumu rastlantıya bağlı, kolay elde edilebilir, göreli olarak ucuz, ancak işletmesi pahalı arazi parçalarında yapılmak zorunda kalınır. İnsanlar kamu hizmetlerine ulaşmada 
zorluk çeker. Hizmetlerin verildiği alanlara ulaşılabilirlik sorunları meydana getirir. Bu durum sürdürülebilir kentleşme olgusunun, kamusal hizmetlerin sağlıklı ulaştırılması ve kaynakların doğru kullanımı ilkeleriyle örtüşmez.

\subsection{Engel / Toplumsal Adalet Sorunları}

Bedeli kamu tarafından ödenen imar çalışmalarıyla ortaya çıkarılan kentsel arsaların doğurduğu ekonomik rantın tekrar kamuya aktarılmayarak, bireylere dönmesi, bir taraftan toplumda gelir dağılımını olumsuz etkiler, diğer taraftan gelecekte tekrar gereksinim duyulacak mali kaynakların teminini zora sokar. Bu durum insanların arsa spekülasyonunu yüksek gelir sahibi olmanın meşru yollarından biri olarak görmesine neden olur. Sürdürülebilir kentleşmenin, toplumsal adalet ve kaynakların doğru kullanımı ilkeleriyle çelişir. Bu bağlamda sürdürülebilir kentleşme sekteye uğratır.

Sonuç olarak 2010'lu yıllar itibariyle Türkiye'nin pek çok kentinde benzer sorunlar yaşanmaktadır. 16.05.1012'de kamuoyunda kentsel dönüşüm yasası olarak bilinen "afet riski altındaki alanlarına dönüşümü hakkında kanun" yürürlüğe girmiştir. Kanun afet riski dışında diğer riskli yapı grupları adı altında, ekonomik ömrünü tanımlamış yapıları da içermektedir. Ancak kanunun uygulanması aşamasında henüz net sonuçlar için erkendir.

\section{Isparta İstasyon Caddesi}

Isparta kenti İstasyon Caddesi ve çevresi coğrafi konumu itibariyle büyük kentleri birbirine bağlayan ana ulaşım yolları üzerinde yer almayan "Arada Kent" (Tümer, 2004) olarak adlandırılabilen Isparta'nın prestijli bir caddesidir. Cadde tarihsel süreç içerisinde sergilediği dönüşüm ile özel mülkiyet artışını, çok parçalı mülkiyet oluşumlarını yaşayan, bu nedenle sürdürülebilirlikten uzaklaşan bir mekândır. Kentleşme sürecinin net biçimde takip edilebilmesi ve sürecin Türkiye'de pek çok kentte yaşanan benzer süreçlere ışık tutabilme potansiyeli açısından çalışma alanı olarak tercih edilmiştir.

İzmir-Denizli demiryolunun uzantısı olan Dinar-Eğirdir demiryolu, Cumhuriyet öncesinde bir İngiliz Şirketi tarafından inşa edilmiştir. Isparta'nın hemen yakınından geçmesine karşın kent merkezine ulaşmayan demiryoluna 1936 yılında Bozanönü - Isparta arası 14 km'lik hat eklenerek demiryolu Isparta'ya ulaştırıımıştır. Hattın inşasının ardından 1936'da istasyon binası dönemin Başbakanı İsmet İnönü tarafından hizmete açılmıştır. İstasyonun inşası ile o döneme kadar tarımsal faaliyetler için kullanılan alanda, İstasyon binası ile kent merkezini bağlayan bir bulvar açılmıştır. İstasyon binasıyla başlayan bulvar 1890'lı yıllarda yapılan, kentin iki önemli resmi kurum binası Tümen Karargâhı ile İdadi Mektebi arasından, Mektep bahçesinden geçirilerek, dönemin önemli caddelerinden Pavyonlar Caddesine bağlanmış, ilk olarak İnönü Bulvarı olarak adlandırımıştır. 


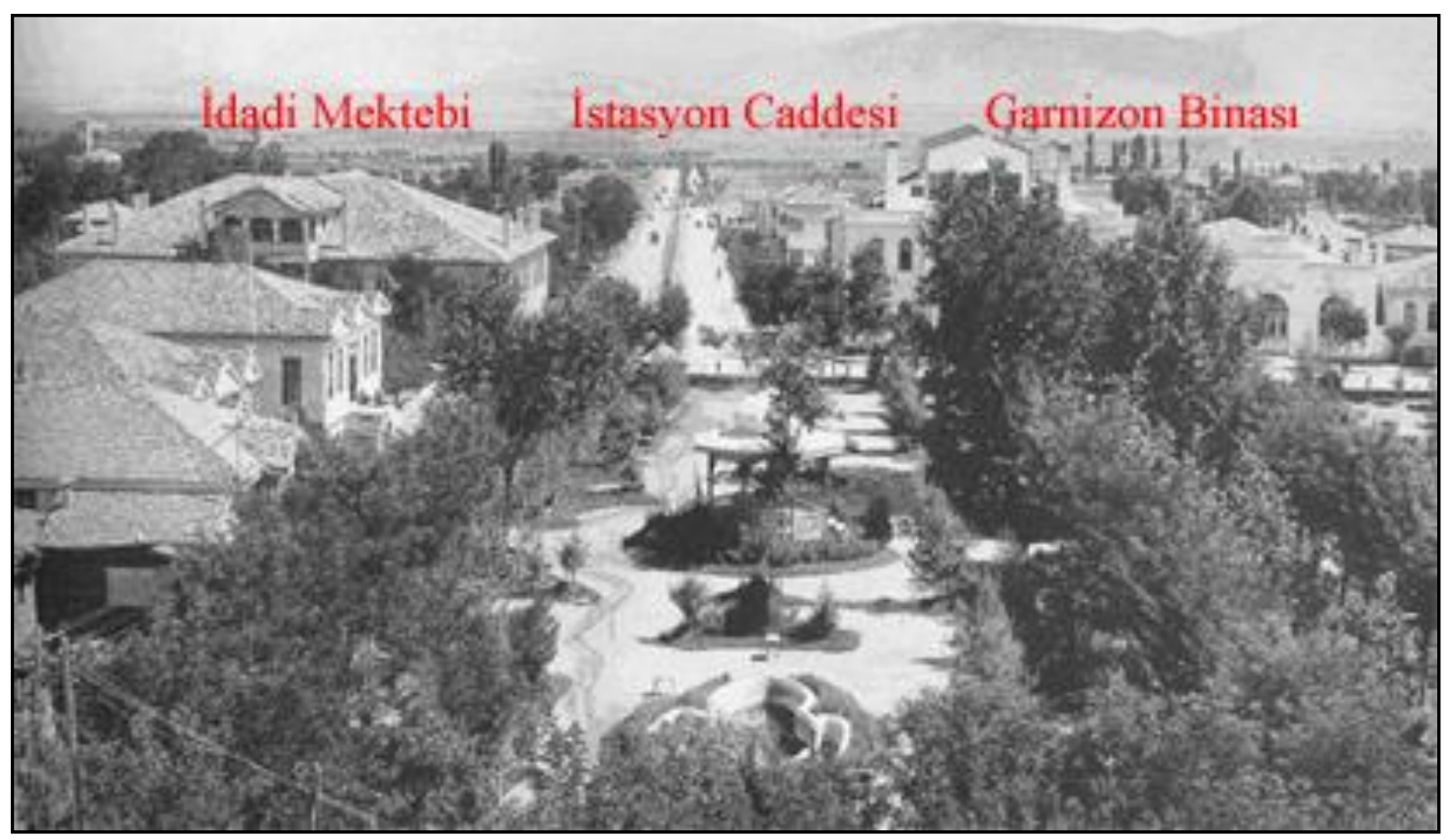

Şekil 1. İstasyon Caddesi, 1936 (Isparta Valiliği, 2001)

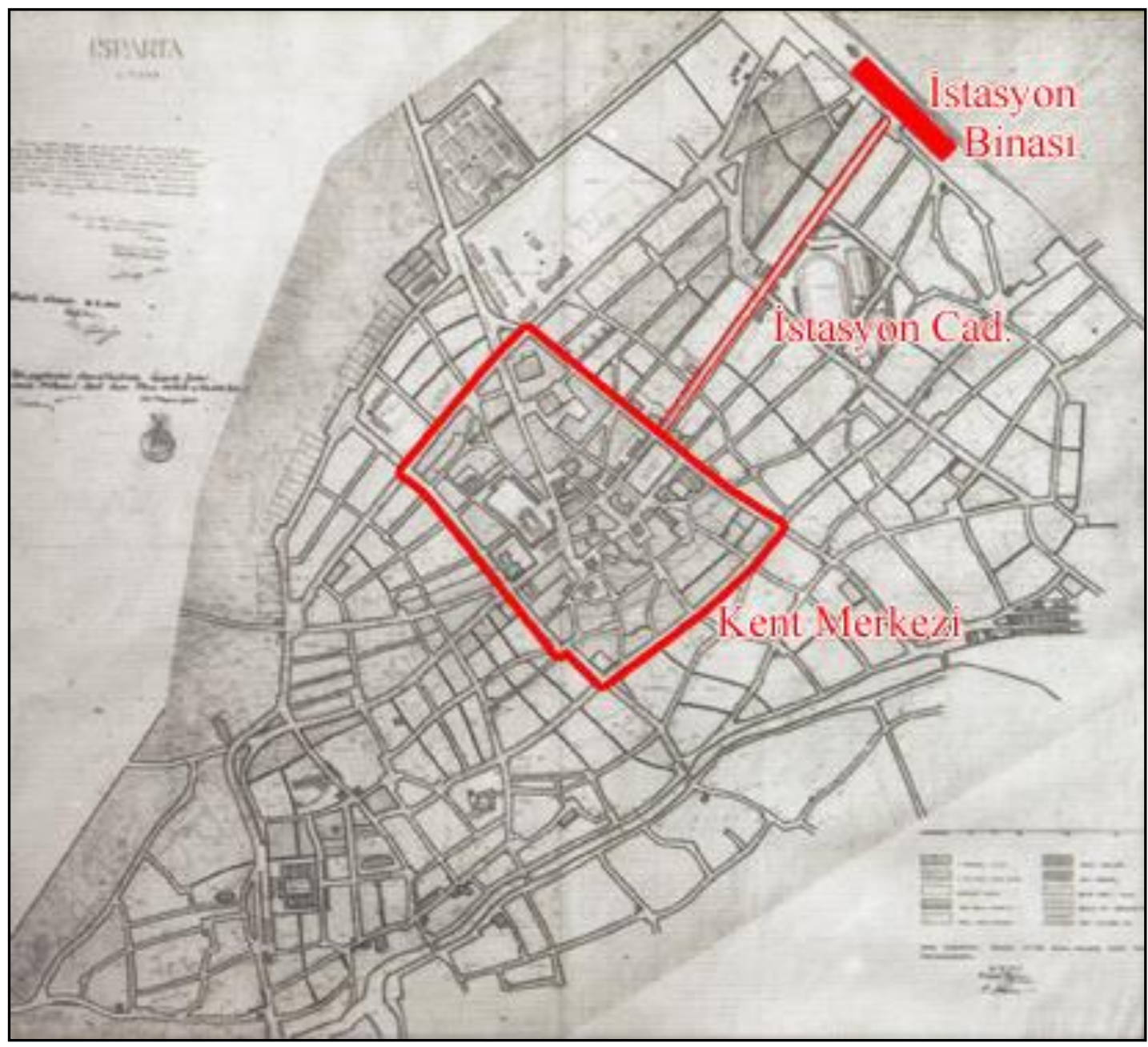

Şekil 2. Isparta'nın ilk imar planında İstasyon Caddesi, 1943 (Isparta Valiliği, 2001) 
İstasyon Caddesinde imar faaliyetleri kentin genelinden farklı değildir. Caddenin 1936'da şose olarak açılmasının ardından 1943'te kentin ilk imar planı hazırlanmıştır. 1950'li yıllar sonrasında kentin geçirdiği dönüşümle birlikte İnönü Bulvarı ve çevresi de dönüşümün içerisinde kalmış, hızla tarımsal arazi olmaktan çıkarak kentsel arsalara dönüşmüştür. Gerek istasyon binasının getirdiği ulaşım imkânı, gerekse Vali Konağı, okullar ve spor tesisleri gibi kamusal alanların ve sosyal donatı alanlarının hızla ortaya çıkması caddenin hızlı kentleşmeyle birlikte cazibe merkezi olmasını sağlamıştır. Bu dönemde cadde boyunca betonarme gibi yeni yapım tekniklerinin kullanıldığı, 2-3 katlı, bahçeli, modern konut dokusu oluşmaya başlamıştır. Bu şekliyle cadde 1960'।ı yılların sürdürülebilir kentleşme değerlerine uygun, sürdürülebilir özellikleri yüksek bir kentsel alan olmuştur.

1965'de yürürlüğe konan Kat Mülkiyeti Kanunu ve 1967 İmar Planı ile birlikte 1970'li yılların sonlarına doğru, 1955- 1965 yılları arasında oluşan yapı stoku yavaş yavaş yok olmaya başlamıştır. Ancak bu çok hızlı bir dönüşüm değildir. Bu nedenle mülkiyet yapısının fazla dönüşüme uğradığı söylenemez. Ancak alanda asıl önemli mülkiyet dönüşümü, 1980 sonrası yaşanan hızlı yapılaşma süreciyle gerçekleşmiştir. Bu dönemde yeni inşaat teknolojilerinin, özellikle betonarme karkas sistemlerin yaygın kullanımı ve imar planında kat adedinin 5 olmasının ortaya çıkardığı ekonomik rantın etkisiyle, İstasyon Caddesi üzerindeki parsellerde çok katlı yapılaşma başlamıştır. Ayrıca kat mülkiyeti olgusunun verdiği imkânla mülkiyet yapısı, parsel içerisinde çok parçalı bir hal almış, tekil mülkiyetli 3 katlı yığma yapıların yerini, içerisinde 10 bağımsız bölüm bulunan 5 katlı apartman blokları almıştır. Diğer deyişle malik sayısı 10 katına çıkmış, bir parselde 3 ailenin barınacağı düşünülerek bırakılan sosyal donatı alanları, bir parselde 10 aileye hizmet vermek zorunda kalmıştır.

Sonuçta 1990'larda cazibe merkezi olan İstasyon Caddesi'nde 2000'li yıllar itibariyle 897 adet konut bulunurken, cadde tamamen yapılaşmıştır. Yapıların tamamı özel mülkiyettedir. Ancak günümüzde yaklaşık 30 yaşına gelen apartmanlar hızla değer yitirmeye başlamıştır. Bu dönemden sonra bölgenin imar planlarının da herhangi bir değişiklik yaşanmamıştır.

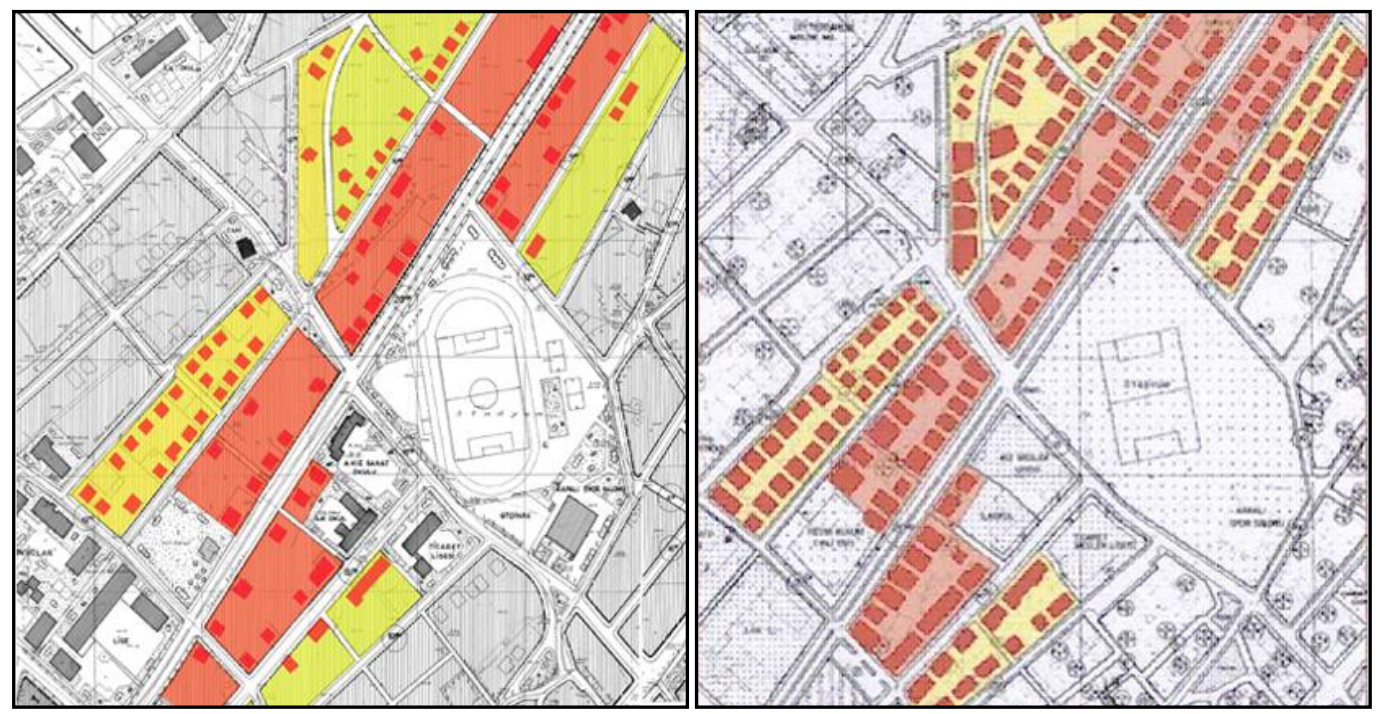

Şekil 3. 1967 ve 1988 imar planlarında yapılaşma durumu (Isparta Belediyesi)

İstasyon Caddesinde yaşanan kentleşme süreci yakından incelediğinde ise çalışmanın başında bahsedilen sürdürebilir kentleşme önündeki engellerin ortaya çıktığı görülür. Öyle ki, İstasyon Caddesi ve çevresinde yapılar çatı katı ve bodrum katlarının dahi konut olarak değerlendirildiği apartman blokları şeklindedir. İnsani boyut kaygısı barındırmayan 5-6 katlı bloklar arası mesafe açık çıkmalardan sonra 4 m'ye kadar düşer. Yeşil alan miktarı cadde refüjü dışında yok denecek kadar azdır. Otopark alanı bulunmaz. Bu nedenle, oluşan yeni mülkiyet yapısının İstasyon Caddesinde birinci engel "Aşırı Yoğunluk" açısından sürdürülebilir kentleşmeyi engellediği söylenebilir.

Türkiye'deki mevcut imar ve mülkiyet mevzuatında, yapısal risk taşıma durumu dışında, mülk sahibini zorlayıcı düzenlemeler olmadığı düşünüldüğünde alanla yeniden planlama ve sağlıklaştırma 
çalışmalarının nasıl gerçekleşeceği önemli bir sorundur. Mülkiyet parçalanması sonucu karar alma süreci zorlaşmıştır. Bununla birlikte çalışmalar için mali kaynağın nasıl temin edileceği belirsizdir. Bu nedenle, oluşan yeni mülkiyet yapısının İstasyon Caddesinde ikinci engel "Karar Alma Süreci" açısından sürdürülebilir kentleşmeyi engellediği söylenebilir.

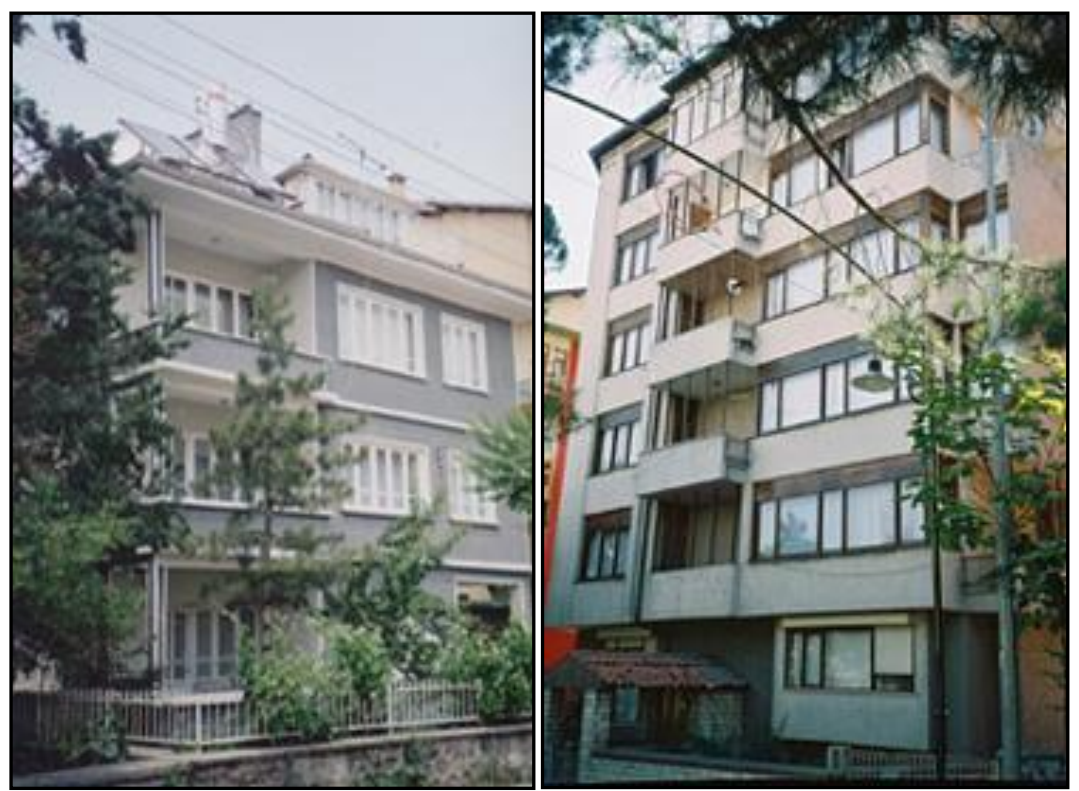

Şekil 4. 1950'ler ve 1980'lerde inşa edilen konutlar

İstasyon Caddesi ve çevresinde dönüşümün başladığı 1960'lı yıllar itibariyle, kamusal hizmetler için 1 ilkokul, 4 lise, vali konağı, stadyum, kapalı spor salonu gibi kamusal hizmet alanları bölgede yer almıştır. Yerleştirilen sosyal donatı alanlarının, ulaşılabilirlik açısından merkezi konumda olduğu söylenebilir. Ancak bu dönemden sonra kamusal hizmetler alan tahsis edilemediği gibi gelecekte gereksinim duyulacak yeni tesislerin nerelere yapılabileceği belli değildir. Yer seçiminde arsa maliyetinin önemli rol oynayacağı düşünülürse bu tesislerin uygun yerlere yapılma ihtimali oldukça düşüktür. Bu nedenle, oluşan yeni mülkiyet yapısının İstasyon Caddesinde üçüncü engel "Kentsel Donatı Alanı" açısından sürdürülebilir kentleşmeyi engellediği söylenebilir.

İstasyon caddesi ve çevresinde dönüşüm sürecinde yıkılarak yeniden yapılan yapıların tamamının müteahhitlere kat karşılığı verilmek usulüyle yaptırıldığı bilinmektedir. Böylece, kamunun imar yoluyla yarattığı rant, mülk sahipleri ve müteahhitler arasında paylaşıldı denebilir. Bu ranttan çevrenin yaşanabilirlik düzeyine ve topluma geri dönen bir paydan söz edilemez. Bu nedenle, oluşan yeni mülkiyet yapısının İstasyon Caddesinde dördüncü engel "Toplumsal Adalet" açısından sürdürülebilir kentleşmeyi engellediği söylenebilir.

\section{Sonuç}

Gerekli çalışmalar geciktirilmeden yapılmadığı ve önlem alınmadığı takdirde kentlerde 2000'li yıllardaki mülkiyet yapısıyla sürdürülebilir kentsel gelişimden söz etmek mümkün olamayacaktır. Hazırlanan kentsel dönüşüm yasasının mevcut çöküntü alanlarının ıslahında çözüm üretmesi olası olmakla birlikte, gelecekte aynı sorunların tekrar yaşanmaması için, sorun çözmek yerine, sorun oluşturmamak düşüncesi ön planda olmalıdır. Çünkü yeni yasa parseller üzerinde yapılacak yeni düzenlemelerle mevcut hak sahiplerine yenilerinin eklenmesine neden olacaktır. Mülkiyet parçalanması devam edecektir. Bu bağlamda, sürdürülebilir kentsel gelişme için, kent planlaması ve uygulamasında etkin olabilecek temel araçlardan biri olarak mülkiyet konusuna gereken önemin verilmesi yerinde olur. Çünkü kentsel sorunların ve bu sorunların planlı çözülmesine ilişkin yasal düzenlemelerin tarihsel gelişimi ile kent topraklarındaki mülkiyetin niteliğinin değişiminde koşutluk vardır. Insanlığa 2000'lerin kentlerinin nasıl olması konusunda yol gösteren sürdürülebilirlik yaklaşımının, kentlerdeki mülkiyet yapısının nasıl olması gerektiği konusunda da yol gösterici kabul 
edilmesinde yarar vardır. Sürdürülebilir kentsel gelişme için kentsel topraklarda, özel ve parçalı mülkiyet yapısını sınırlayacak düzenlemeler hayata geçirilmelidir.

\section{Kaynaklar}

ACE (Avrupa Mimarlar Konseyi), (2005). Mimarlık ve Yaşam Kalitesi, Çev; A. Erim, TMMOB Mimarlar Odası Yayınları, Ankara.

Bullard, R. (2002). Land Ownership and Sustainable Develpoment, FIG XXII. International Congress, April 19-26, USA, Washington D.C.

Ekinci O. (1995) Sürdürülebilir Bir Gelecek İçin Mimarlık, Mimarlar Odası 40.yıl Panelleri, Armoni Matbaacılık, Ankara.

Isparta Valiliği, (2001). Isparta 1880-1980, II Özel İdare Müdürlüğü Yayınları.

Isparta Belediyesi, 1967 ve 1988 İmar Planları, Isparta Belediyesi İmar ve Şehircilik Müdürlüğü, Isparta.

İncedayı, D. (2004). Çevresel Duyarlıık Bağlamında Davranış Biçimi Olarak Sürdürülebilirlik, Mimarlık Dergisi, Sayı 308, s.43.

Jökel, R. (2003). Sustainable Urban Development in Cases of Complicated Land Ownership Situations, FIG Working Week, April 13-17, France.

Keleş, R. ( 1984). Kentleşme ve Konut Politikası, A Ü.S.B.F Yayınları, Ankara.

Okutan, A. (1995). Türkiye'de Kentleşme ve Siyasal Yapı, Türk Demokrasi Vakfı Yayınları, Ankara.

Tekeli, İ. (1999). Sürdürülebilirlik Kavramı Üzerine İrdelemeler, Prof. Dr. Cevat Geray'a Armağan, Mülkiyeliler Birliği Yayınları, s. 729 -746, Ankara.

Tümer, G. (2004). Arada Kentler, Arada Kentler Paneli Kitabı, TMMOB Mimarlar Odası Yayınları, Ankara.

Yavuz, F. (1980). Kentsel Topraklar, S.B.F. Basımevi, Ankara. 